\title{
Studi Osifikasi Anggota Tubuh Embrio Ayam Buras dengan Pewarnaan Alizarin Red
}

\author{
Study of a Embryonic Organ Member of the Buras Chicken with Pigmentation \\ Alizarin Red \\ Fatimatuz Zahrotul Husna ${ }^{*}$, Hari Santoso $\left.{ }^{* *}\right)$ Ratna Djuniwati Lisminingsih ${ }^{* * *}$ \\ Jurusan Biologi Fakultas Matematika dan Ilmu Pengetahuan Alam Universitas Islam Malang, Indonesia
}

\begin{abstract}
ABSTRAK
Ayam buras adalah turunan dari proses penyilangan ayam hutan dengan ayam pedaging, yang didomestikasi dan dikembang-biakan. Osifikasi anggota tubuh embrio ayam diawali dari tulang rawan dan berkembang menjadi tulang keras. Penelitian ini bertujuan untuk mengetahui osifikasi embrio ayam umur 9, 13, 17 dan 21 hari. Metode penelitian digunakan deskriptif kuantitatif dengan purposive sampling, dengan pewarna alizarin red. Hasil penelitian menunjukkan adanya perbedaan warna tulang embrio ayam dari merah muda sampai merah keunguan. Bagian tulang yang terosifikasi meliputi humerus, radius, ulna, carpometacarpo, femur, tibiotarsus, tarsometatarsus dan digiti. Tulang yang berwarna merah keunguan pada embrio umur 9 hari adalah carpometacarpo, ulna, radius, humerus, femur, tibia dan tarsometatarso, yang berwarna merah muda yakni pada seluruh tulang digiti dan pollex. Pada embrio umur 13 hari adalah digiti ke 2, carpometacarpo, pollex, ulna, radius, humeru, femur, tibia, tarsometatarso, digiti ke 1, digiti ke 2 dan digiti ke 3, yang berwarna merah muda yakni digiti ke 1 dan ke 3 pada sayap dan digiti ke 4 pada kaki . Pada umur 17 hari digiti ke 1, digiti ke 2, carpometacarpo, pollex, ulna, radius, humerus, femur, tibia, tarsometatarso,digiti ke 1, digiti ke 2, digiti ke 3 dan digiti ke 4 dan yang berwarna merah muda digiti ke 4 pada kaki. Pada umur 21 hari digiti ke 1, digiti 2, digiti 3, carpometacarpo, pollex,radius, ulna, humerus, femur, tibia, tarsometatarso, digiti ke 1, digiti ke 2, digiti ke 3 dan digiti ke 4 . Tulang yang berwarna merah keunguan telah mengalami osifikasi sedangkan tulang yang berwarna merah muda belum mengalami osifikasi.
\end{abstract}

Kata kunci: embrio, osifikasi, alizarin red.

\begin{abstract}
Free-range chicken is derivative of the process a cross patridge with broiler, that domesticated and cultivated. Osification limb embryos of chickens started with cartilage and develop into the hard bone. This study aims to know ossification of the embryo chicken the age of 9, 13, 17 and 21 days. Research methodology used descriptive quantitative with purposive sampling, with alizarin red. The results of the study shows differences in color chicken bone the embryo from pink to red in wait. The bone that ossification is humerus, radius, ulna, carpometacarpo, femur, tibiotarsus, tarsometatarsus and digiti. Differences in the hues occurs in the age of an embrio 9 day portion of a bone in red parents is carpometacarpo, ulna, radius, humerus, femur, tibia and tarsometatarso. In the embryo chicken age 13 days is digiti ke 2, carpometacarpo, pollex, ulna, radius, humeru, femur, tibia, tarsometatarso, first digiti, second digiti and third digiti. In the embryo chicken age 17 days is first digiti, second digiti, carpometacarpo, pollex, ulna, radius, humerus, femur, tibia, tarsometatarso, first digiti, second digiti, third digiti and fourth digiti. In the embryo chicken age 21 days is first digiti, second digiti, third digiti, carpometacarpo, pollex,radius, ulna, humerus, femur, tibia, tarsometatarso, first digiti, second digiti, third digiti and fourth digiti.A bone that is of purplish red color has been undergoes ossification whilw a bone that is of pink in color have not yet undergone ossification.
\end{abstract}

Keywords: embryo, calcification, ossification, alizarin red.

\footnotetext{
*) Fatimatuz Zahrotul Husna, Jurusan Biologi FMIPA UNISMA, J1. MT Haryono 193, Malang 65144 Tlp. 085733320558 email: fatimatuzzahrotulhusna@gmail.com

**) Drs. H Hari Santoso M. Biomed, Jurusan Biologi FMIPA UNISMA, Jl. MT Haryono 193, Malang 65144 Tlp. 082331449560 email: harisantoso.m.biomed@gmail.com
}

$$
\text { Diterima Tanggal } 4 \text { Pebruari } 2019 \text { - Diterbitkan Tanggal } 25 \text { Januari } 2020
$$




\section{Pendahuluan}

Ayam buras merupakan salah satu jenis ternak yang potensial untuk dikembangkan dan telah memasyarakat di seluruh pelosok nusantara. Ayam buras merupakan plasma nutfah yang keberadaannya perlu dilestarikan [1]. Produktivitas ayam buras relatif rendah, sehingga masih berpotensi untuk dikembangkan dan ditingkatkan [2]. Telur ayam akan menetas setelah diinkubasi selama 21 hari dengan melalui serangkaian perkembangan embrio secara komplek. Perkembangan embrio ayam mulai dari fertilisasi, blastulasi, gastrulasi, neurolasi dan organogenesis. Fertilisasi adalah penggabungan sel kelamin jantan dan sel kelamin betina membentuk zigot. Selanjutnya zigot mengalami pembelahan secara mitosis. Blastula merupakan tahap lanjutan dari stadium pembelahan berupa massa blastomer membentuk dasar calon tubuh ayam, pada tahap ini terbentuk blastoselom. Gastrula ialah proses kelanjutan stadium blastula, tahap akhir dari proses gastrulasi ditandai dengan terbentuknya coelom dan sumbu embrio sehingga embrio mulai tumbuh memanjang Tubulasi adalah kelanjutan dari proses stadium gastrula. Embrio pada stadium ini disebut dengan neurula karena pada tahap ini terjadi neurulasi yakni pembentukan bumbung neural. Organogensis merupakan tahap selanjutnya yaitu perkembangan dari bentuk primitif embrio menjadi bentuk definitif yang memiliki bentuk dan rupa yang spesifik dalam satu spesies. Selain itu juga diikuti dengan terbentuknya tulang rangka pada embrio. Tulang pada makhluk hidup berperan penting dalam aktivitas gerak. Pada hewan ternak khususnya ayam, perkembangan tulang menentukan kualitas dan produktivitas. [3].

Kualitas tulang rangka (skeleton) atau kekuatan tulang pada ayam ternak merupakan salah satu faktor yang penting dalam menentukan kualitas ayam ternak.Pertumbuhan tulang yang seimbang dengan penambahan masa tubuh merupakan hal sangat penting dalam perkembangan ternak ungags [4]. Kemudian terdapat berbagai macam kelainan patologis pada tulang ayam, contohnya seperti distorsi tulang panjang dan dischondroplasia [5]. Oleh karena itu perlu diketahui osifikasi pada embrio ayam, yakni dengan melakukan pewarnaan pada embrio menggunakan pewarna Alizarin Red untuk mengetahui perkembangan tulang yang terjadi. Dimana Alizarin Red adalah proses pewarnaan tulang berguna sebagai pendeteksi adanya proses osifikasii di daerah tulang yang terwarnai [6]. Proses pewarnaan dengan Alizarin Red menyebabkan tulang akan berwarna merah tua, yang menandakan bahwa tulang telah mengalami osifikasii. Proses osifikasii pada embrio ayam dapat diamati ketika umur mulai dierami selama 9 hari [7].

\section{Material dan Metode}

\section{Bahan dan Alat}

Alat yang digunakan dalam penelitian ini adalah inkubator, alat bedah, mangkuk, tempat spesimen berupa botol, cawan petri, jangka sorong, mikroskop cahaya, mikroskop stereo dan pipet tetes.

Bahan yang digunakan pada penelitian ini adalah embrio ayam yang diinkubator selama 9 hari, 13 hari dan 17 hari dan 21 hari, larutan alkohol 95\%, larutan pewarna Alizarin red, larutan penjernih A, larutan penjernih $\mathrm{B}$, larutan penjernih $\mathrm{C}$, larutan $\mathrm{KOH} 1 \%$, larutan gliserin murni, larutan garam fisiologis, tymol dan aquades

\section{Metode}

Ditinjau dari segi prosedur dan pola yang ditempuh oleh peneliti dalam penelitian ini, termasuk jenis penelitian deskriptif kuantitatif. dalam penelitian ini teknik sampling yang digunakan yaitu teknik purposive sampling, sampel yang digunakan adalah 5 untuk tiap kelompok.

Analisis Data:Pada embrio ayam yang telah diwarnai diamati bagian sayap dan kakinya dilihat tulang apa saja yang telah mengalami osifikasi dimana ditandai dengan perubahan warna dari bening menjadi merah tua sampai ungu. Sebagai data penunjang diukur berapa panjang tulang yang mengalami perubahan warna menggunakan alat ukur yakni jangka sorong dan mikroskop. Jangka sorong digunakan untuk skala makroskopik dan mikroskop untuk skala mikroskopik. Setelah itu dibandingkan hasil dari tiam embrio dari tiap umur. 


\section{Cara Kerja}

Diambil telur ayam fertil yang telah diinkubasi selama 9 hari, 13 hari dan 17 hari dan 21 hari dikeluarkan dari dalam cangkang dan diletakkan pada mangkuk yang telah diisi garam fisiologis. Dibersihkan embrio dari membran ekstra embrional. Bila embrio telah memiliki bulu, maka bulu-bulu tersebut dihilangkan agar tidak mengganggu pada saat identifikasi tulang yang telah mengalami osifikasii. Setelah embrio dibersihkan kemudian dimasukkan dalam botol bening yang telah diisi larutan alkohol 95\%. embrio direndam dalam larutan alkohol ini selama kurang lebih 12 jam. Dibuang larutan alkohol dan dipindahkan embrio kedalam botol yang berisi larutan $\mathrm{KOH} 1 \%$ dan dibiarkan dalam larutan tersebut hingga otot menjadi transparan dan skeletonnya terlihat jelas. Setelah jaringan otot transparan, embrio dipindahkan kedalam wadah yang berisi larutan pewarna Alizarin Red dan direndam dalam larutan ini hingga skeleton berwarna merah tua atau ungu (kurang lebih selama 3 jam). Selanjutnya embrio dipindahkan kedalam larutan $\mathrm{KOH} \mathrm{2 \% .} \mathrm{Embrio} \mathrm{direndam} \mathrm{dalam} \mathrm{larutan} \mathrm{ini} \mathrm{selama}$ kurang lebih 30 menit agar jaringan otot benar-benar menjadi transparan. Dipindahkan embrio ke dalam larutan penjernih A selama 1 jam kemudian kedalam larutan penjernih B dan C masing-masing selama $1 \mathrm{jam}$. Kemudian dipindahkan embrio ke dalam larutan gliserin murni yang telah diberi tymol. Diamati bagian tulang yang terwarnai. Dibandingkan system rangka embrio tiap umur yang sudah terwarnai. Pembuatan larutan penjernih . Larutan pernjernih A : Gliserin (20 bagian), $\mathrm{KOH} \mathrm{4 \%} \mathrm{(3} \mathrm{bagian)} \mathrm{dan}$ akuades (77bagian). Larutan penjernih B : Gliserin (50bagian), $\mathrm{KOH} \mathrm{4 \%} \mathrm{(3} \mathrm{bagian),} \mathrm{dan} \mathrm{akuades} \mathrm{(25}$ bagian). Larutan penjernih $\mathrm{C}$ : Gliserin (75 bagian) dan aquades (25 bagian) [8].

\section{Hasil dan Diskusi}

\section{Hasil Penelitian}

Tabel hasil pengamatan perubahan warna pada tulang sayap embrio ayam umur 9 hari, 13 hari, 17 hari dan 21 hari setelah proses pewarnaan menggunakan pewarna alizarin red.

Tabel 1. Pengamatan Hasil Perubahan Warna Pada Sayap Embrio Ayam Umur 9 Hari, 13 Hari, 17 Hari dan 21 Hari.

\begin{tabular}{llcccc}
\hline NO & \multicolumn{1}{c}{ Tulang } & $\begin{array}{c}\text { Emrio Umur } \\
9 \text { hari }\end{array}$ & $\begin{array}{c}\text { Embrio } \\
\text { Umur 13 } \\
\text { hari }\end{array}$ & $\begin{array}{c}\text { Embrio } \\
\text { Umur 17 } \\
\text { hari }\end{array}$ & $\begin{array}{c}\text { Embrio } \\
\text { Umur 21 } \\
\text { hari }\end{array}$ \\
\hline 1. & Phalang & - & & & \\
& Digiti 1 & - & - & $\sqrt{ }$ & $\sqrt{ }$ \\
& Digiti 2 & - & $\sqrt{ }$ & $\sqrt{ }$ & $\sqrt{ }$ \\
& Digiti 3 & $\sqrt{ }$ & $\sqrt{ }$ & $\sqrt{ }$ & $\sqrt{ }$ \\
2. & Carpometacarpo & - & $\sqrt{ }$ & $\sqrt{ }$ & $\sqrt{ }$ \\
3. & Pollex & $\sqrt{ }$ & $\sqrt{ }$ & $\sqrt{ }$ & $\sqrt{ }$ \\
4. & Ulna & $\sqrt{ }$ & $\sqrt{ }$ & $\sqrt{ }$ & $\sqrt{ }$ \\
5. & Radius & $\sqrt{ }$ & $\sqrt{ }$ & $\sqrt{ }$ & $\sqrt{ }$ \\
6. & Humerus & & &
\end{tabular}

$\sqrt{ }=$ Terdapat tulang yang mengalami perubahan warna menjadi merah.

$-=$ Belum terdapat tulang mengalami perubahan warna menjadi merah.

Dari hasil pengamatan makroskopik (Tabel 1), pada bagian sayap embrio ayam umur 9 hari, 13 hari, 17 hari dan 21 hari terdapat perbedaan pada bagian tulang yang telah mengalami osifikasii. Osifikasii ditandai dengan perubahan warna pada tulang dari jernih menjadi merah [6]. Dimana didapati hasil pada embrio umur 9 hari masih sedikit tulang yang mengalami osifikasii yakni hanya pada bagian Carpometacarpo, Ulna, Radius dan humerus. Untuk bagian phalang dan pollex belum terjadi. Pada embrio umur 9 hari pengamatan osifikasi telah dapat dilakukan, pembentukan sistem rangka dimulai 
pada inkubator hari ke 5 yang ditandai dengan kondensasi mesenkim prekartilago, kondrifikasi dimulai pada hari ke 8 sedangkan osifikasi pertamakali dimulai pada hari ke 9 inkubasi [9]. Embrio umur 9 hari pada bagian tulang panjang seperti humerus, ulna, radius dan carpometacarpo tergolong osifikasi interkartilagous dimana tulang keras diawali oleh pembentukan tulang rawan yang kemudian akan dirombak, osifikasi ini diawali dari bagian tengah dari tulang yang kemudian akan meluas ke seluruh arah dengan pertumbuhan tulang rawan. Pada tulang ini ketika diamati secara makroskopis terlihat sepeti titik merah pada bagian tengan tulang. Kemudian setelah diamati secara mikroskopis terlihat jelas tulang yang telah mengalami osifikasii. Panjang tulang yang telah mengalami osifikasii yakni humerus 2,8 $\mathrm{mm}$, ulna 3,2 $\mathrm{mm}$ radius $3 \mathrm{~mm}$ dan carpometacarpo $1,4 \mathrm{~mm}$.

Pada embrio umur 13 hari tulang yang telah mengalami osifikasii adalah digiti ke 2, carpometacarpo, pollex, ulna, radius dan humerus. Pada bagian digiti ke 1 dan ke 3 belum terjadi osifikasii akan tetapi digiti ke 2 telah terjadi osifikasii, Berbeda dengan embrio umur 9 hari pada tulang digiti belum mengalami osifikasii sama sekali. Pengamatan morfometrik pada bagian tulang didapatkan hasil unuk panjang tulang yang telah mengalami osifikasii pada humerus $3,8 \mathrm{~mm}$, radius $3,5 \mathrm{~mm}$, ulna $3,5 \mathrm{~mm}$, pollex $0,4 \mathrm{~mm}$, carpometacarpo $2,8 \mathrm{~mm}$, digiti kedua 0,2 mm. Pada embrio umur 17 hari yakni digiti ke 1, digiti ke 2, carpometacarpo, pollex, ulna, radius dan humerus. Dengan panjang masing - masingnya asdalah humerus $6 \mathrm{~mm}$, Radius 5,6 mm, ulna 5,6 $\mathrm{mm}$, pollex $0,75 \mathrm{~mm}$ carpometacarpo 3,35 mm digiti kesatu 0,9 $\mathrm{mm}$ dan digiti kedua 0,65 $\mathrm{mm}$. Sedangkan pada Umur 21 hari bagian tulang yang telah mengalami osifikasii adalah digiti ke 1, digiti 2, digiti 3, carpometacarpo, pollex dan ulna. Dengan panjang masing-masing adalah 2,25 mm, 1,7 mm, 0,65 mm, 7,15 mm, 2,15 $\mathrm{mm}, 9,5 \mathrm{~mm}, 9,5 \mathrm{~mm}$ dan $10,45 \mathrm{~mm}$.

Tabel 2. Rerata Panjang Tulang Sayap dan Standart Deviasi

\begin{tabular}{llcccc}
\hline No & \multicolumn{1}{c}{ Tulang } & $\begin{array}{c}\text { Emrio } \\
\text { Umur 9 hari } \\
(\mathrm{mm})\end{array}$ & $\begin{array}{c}\text { Embrio } \\
\text { Umur 13 } \\
\text { hari(mm) }\end{array}$ & $\begin{array}{c}\text { Embrio } \\
\text { Umur 17 } \\
\text { hari (mm) }\end{array}$ & $\begin{array}{c}\text { Embrio } \\
\text { Umur 21 } \\
\text { hari (mm) }\end{array}$ \\
\hline 1. & Phalang & & & & \\
& -. Jari 1 & - & - & $0,90 \pm 0,06$ & $2,25 \pm 0,09$ \\
& -. Jari 2 & - & $0,20 \pm 0,04$ & $0,65 \pm 0,05$ & $1,70 \pm 0,13$ \\
& -. Jari 3 & - & - & - & $0,65 \pm 0,06$ \\
2. & Carpometacarpo & $1,40 \pm 0,10$ & $2,80 \pm 0,06$ & $3,35 \pm 0,05$ & $7,15 \pm 0,03$ \\
3. & Pollex & - & $0,40 \pm 0,08$ & $0,75 \pm 0,03$ & $2,15 \pm 0,03$ \\
4. & Ulna & $3,20 \pm 0,120$ & $3,50 \pm 0,19$ & $5,60 \pm 0,09$ & $9,50 \pm 0,14$ \\
5. & Radius & $3,00 \pm 0,12$ & $3,50 \pm 0,19$ & $5,60 \pm 0,09$ & $9,50 \pm 0,14$ \\
6. & Humerus & $2,80 \pm 2,80$ & $3,80 \pm 0,06$ & $6,00 \pm 0,79$ & $10,45 \pm 0,07$ \\
\hline
\end{tabular}

Tabel 3. Pengamatan hasil perubahan warna pada kaki embrio Ayam umur 9 hari, 13 hari, 17 hari dan 21 hari.

\begin{tabular}{llcccc}
\hline NO & Tulang & $\begin{array}{c}\text { Emrio } \\
\text { Umur 9 } \\
\text { hari }\end{array}$ & $\begin{array}{c}\text { Embrio } \\
\text { Umur 13 } \\
\text { hari }\end{array}$ & $\begin{array}{c}\text { Embrio } \\
\text { Umur 17 } \\
\text { hari 9 }\end{array}$ & $\begin{array}{c}\text { Umur 21 } \\
\text { hari }\end{array}$ \\
\hline 1. & Femur & $\sqrt{ }$ & $\sqrt{ }$ & $\sqrt{ }$ & $\sqrt{ }$ \\
2. & Tibiotarsus & $\sqrt{ }$ & $\sqrt{ }$ & $\sqrt{ }$ & $\sqrt{ }$ \\
3. & Tarsometatarsus & $\sqrt{ }$ & $\sqrt{ }$ & $\sqrt{ }$ & $\sqrt{ }$ \\
4. & Phalang jari 1 & - & $\sqrt{ }$ & $\sqrt{ }$ & $\sqrt{ }$ \\
5. & Phalang jari 2 & - & $\sqrt{ }$ & $\sqrt{ }$ & $\sqrt{ }$ \\
6. & Phalang jari 3 & - & $\sqrt{ }$ & $\sqrt{ }$ & $\sqrt{ }$ \\
\hline 7. & Phalang jari 4 & - & - & & \\
\hline
\end{tabular}

$\sqrt{ }=$ Terdapat tulang yang mengalami perubahan warna menjadi merah.

$-=$ Belum terdapat tulang mengalami perubahan warna menjadi merah. 
e-Jurnal Ilmiah BIOSAINTROPIS (BIOSCIENCE-TROPIC)

Volume 5/ No.: 2 / Halaman 30 - 37 / Januari Tahun 2020

ISSN : 2460-9455 (e) - 2338-2805(p)

Tabel 4. Data Panjang Tulang Kaki dan Standart Deviasi Tulang Kaki

\begin{tabular}{cccccc}
\hline NO & Tulang & $\begin{array}{c}\text { Emrio } \\
\text { Umur 9 hari }\end{array}$ & $\begin{array}{c}\text { Embrio } \\
\text { Umur 13 } \\
\text { hari }\end{array}$ & $\begin{array}{c}\text { Embrio } \\
\text { Umur 17 } \\
\text { hari }\end{array}$ & $\begin{array}{c}\text { Embrio Umur } \\
\mathbf{2 1} \text { hari }\end{array}$ \\
\hline 1. & Femur & $2,60 \pm 0,03$ & $4,50 \pm 0,15$ & $9,70 \pm 0,15$ & $18,45 \pm 0,26$ \\
\hline $\mathbf{2}$ & Tibiotarsus & $2,00 \pm 0,13$ & $6,20 \pm 0,06$ & $12,25 \pm 0,18$ & $23,75 \pm 0,43$ \\
3. & Tarsometatarsus & & & & \\
& & $2,40 \pm 0,07$ & $4,15 \pm 0,15$ & $10,00 \pm 1,56$ & $16,30 \pm 0,56$ \\
\hline 4. & Phalang jari 1 & & & & \\
& -. Ruas 1 & 0 & $0,28 \pm 0,05$ & $2,00 \pm 0,16$ & $3,40 \pm 0,34$ \\
& & & & & \\
\hline 5. & Phalang jari 2 & & 0 & $4,00 \pm 0,18$ & $4.40 \pm 0,17$ \\
& -. Ruas 1 & 0 & $0,40 \pm 0,06$ & $2,80 \pm 0,17$ & $3,10 \pm 0,06$ \\
& -. Ruas 2 & 0 & & & \\
6. & Phalang jari 3 & & $0,40 \pm 0,09$ & $3,80 \pm 0,14$ & $4,25 \pm 0,16$ \\
& -. Ruas 1 & 0 & $0,20 \pm 0,05$ & $2,40 \pm 0,14$ & $2,95 \pm 0,07$ \\
& -. Ruas 2 & 0 & 0 & $2,80 \pm 0,17$ & $4,00 \pm 0,18$ \\
& -. Ruas 3 & 0 & & & \\
7. & Phalang jari 4 & & 0 & $2,40 \pm 0,10$ & $2,45 \pm 0,34$ \\
& -. Ruas 1 & 0 & 0 & $0,80 \pm 0,08$ & $1,70 \pm 0,13$ \\
& -. Ruas 2 & 0 & 0 & $0,40 \pm 0,08$ & $1,30 \pm 0,14$ \\
& -. Ruas 3 & 0 & 0 & $1,00 \pm 0,15$ & $2,00 \pm 0,18$ \\
\hline
\end{tabular}

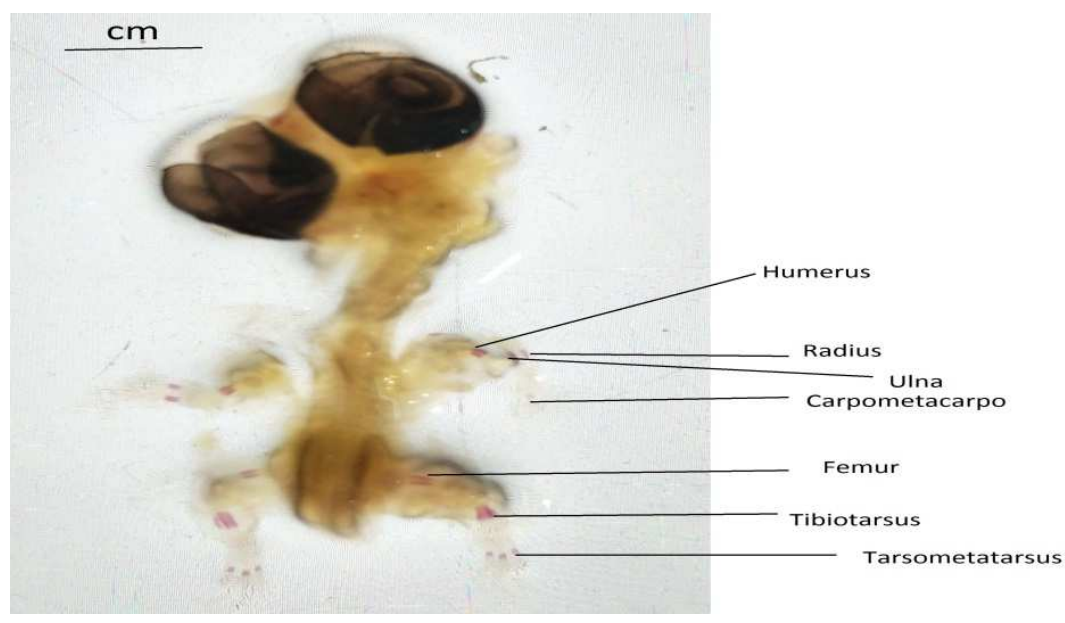

Gambar 1. Embrio Ayam Umur 9 Hari Setelah Proses Pewarnaan.

Dari hasil pengamatan embrio ayam umur 9 hari, 13 hari, 17 hari dan 21 hari (Gambar $1-4)$ terdapat perbedaan dimana diperoleh hasil pada embrio umur 9 hari untuk bagian kaki dan sayap pada perolehan data menunjukkan pada embrio umur 9 hari. Os humerus yang disebut ekstremitas atas berkembang lebih cepat dibandingkan perkembangan os femur yang disebut ekstremitas bawah sehingga osifikasi ekstremitas atas lebih dahulu terjadi daripada ekstremitas bawah [10]. Pada embrio 9 hari didapatkan tulang yang telah mengalami osifikasii yakni femur, tibiotarsus dan tarsometatarsus. Dengan panjang masing-masing adalah $2,6 \mathrm{~mm}, 2 \mathrm{~mm}$, dan $2,4 \mathrm{~mm}$. Pada pengamatan secara makroskopis tulang yang telah mengalami osifikasii dijumpai titik-titik berwarna merah pada bagian 
e-Jurnal Ilmiah BIOSAINTROPIS (BIOSCIENCE-TROPIC)

Volume 5/ No.: 2 / Halaman 30 - 37 / Januari Tahun 2020

ISSN : 2460-9455 (e) - 2338-2805(p)

tengan. Hal ini selain menunjukkan bahwa telah terjadi adanya osifikasii juga menujukkan bahwa pada tulang panjang ( femur, tibiotarsus dan tarsometatarsus) adalah tergolong osifikasi interkartilagous.

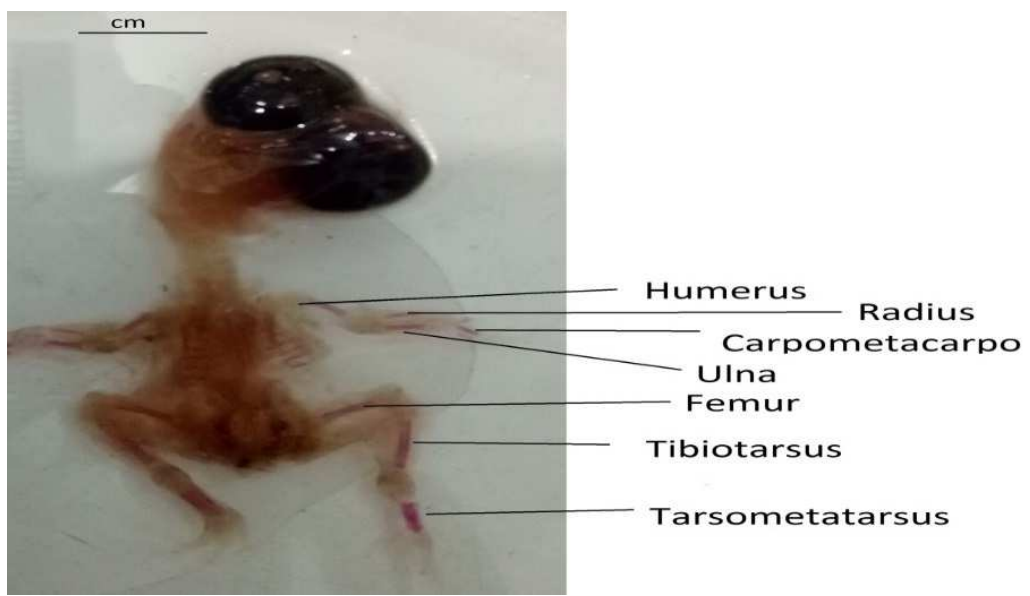

Gambar 2. Embrio Ayam Umur 13 Hari Setelah Proses Pewarnaan.

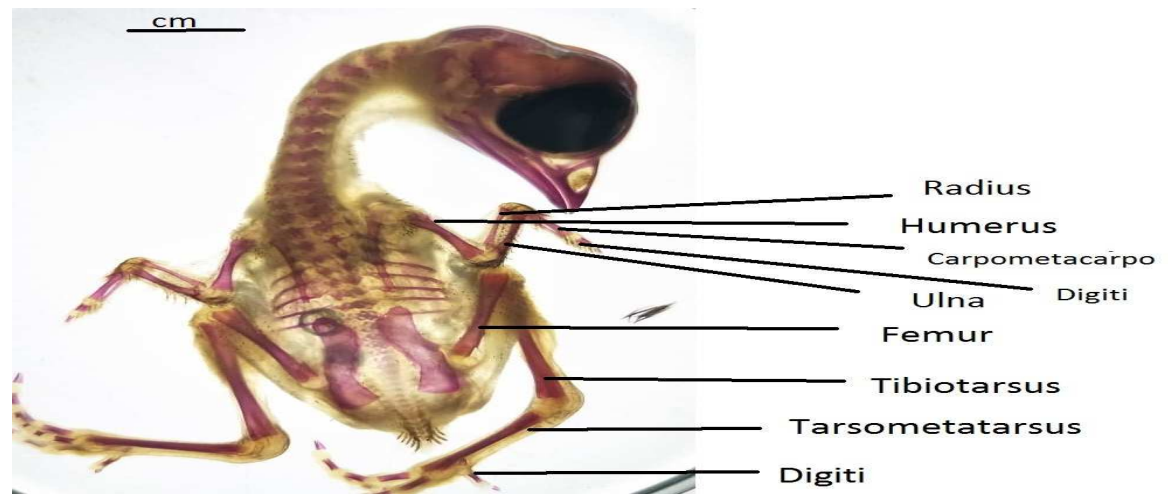

Gambar 3. Embrio Ayam Umur 17 Hari Setelah Proses Pewarnaan.

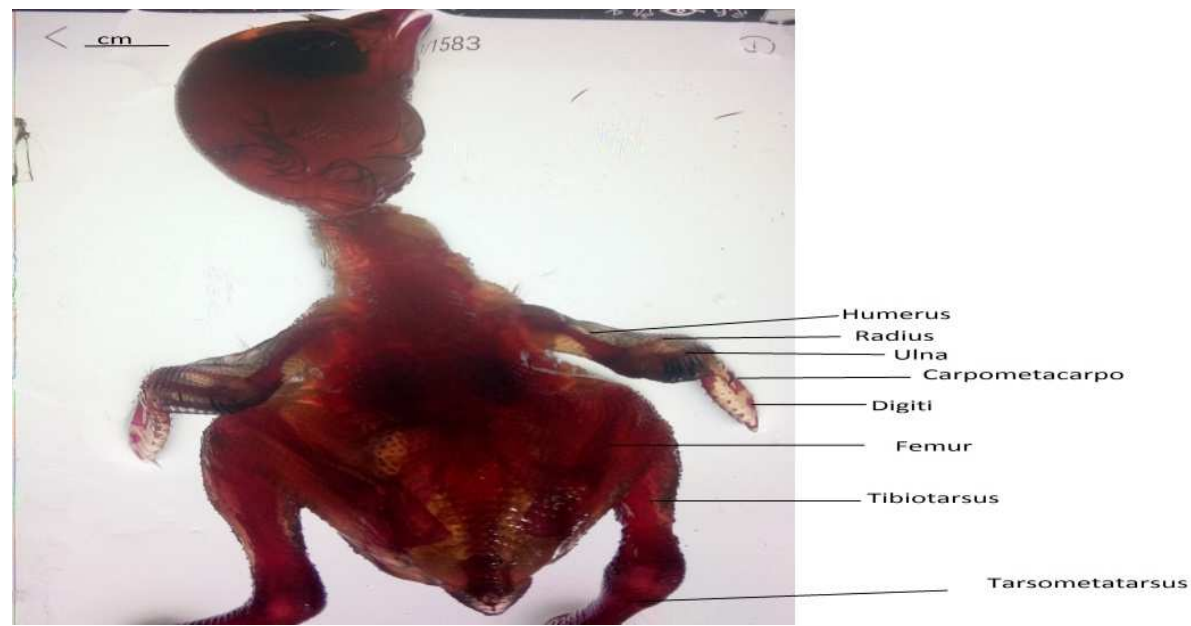

Gambar 4. Embrio Ayam Umur 21 Hari Setelah Proses Pewarnaan. 
Seiring dengan penambahan umur embrio maka tulang akan mengalami pergerakan osifikasii ke bagian ujung-ujung tulang, sehingga seluruh bagian tulang yang semula berupa tulang rawan akan berubah menjadi tulang keras. Pada embrio umur 13 hari tulang yang mengalami osifikasii yakni femur, tibiotarsus, tarsometatarsus, phalang digiti ke 1 ke 2 dan ketiga. Akan tetapi pada tulang digiti belum semua tiap ruas mengalami osifikasii, pada hari ke 13 untuk digiti ke 1 dan ke 2 hanya 1 ruas yang telah mengalami osifikasii. Sedangkan digiti ketiga 2 ruas jari telah mengalami osifikasii. Kemudian untuk embrio aumur 17 hari tulang yang telah terosifikasii yakni femur, tibiotarsus, tarsometatarsus, digiti ke 1, digiti ke 2, digiti ke 3 dan digiti ke 4. Pada embrio umur 17 hari telah mengalami perkembangan pada bagian tulang digiti dimana ke empat digiti telah mengalami osifikasii. Begitu juga pada embrio umur 21 hari pada tulang femur, tibiotarsus, tarsometatarsus dan ke 4 digiti telah mengalami osifikasii yang membedakan ialah ukuran panjang dari tiap tulang yang mengalami perkembangan. Untuk data morfometrik dapat dilihat pada Tabel 2.

Pada Tabel 3 dan Tabel 4 terlihat bahwa osifikasi pada anggota tubuh pada embrio ayam semakin meningkat di setiap tahapan pertambahan usia 9 hari sampai ayam berusia 1 hari, hal tersebut berdasarkan ukuran panjang dari tulang yang telah mengalami osifikasii serta laju pertumbuhan panjang perhari yang dilihat dari nilai standar deviasi pada Tabel 4 . Hal ini berarti bahwa ayam mengalami pertumbuhan. Secara umum pertumbuhan ialah peningkatan ukuran atau volume dari zat hidup [11].

\section{Kesimpulan}

Pada sayap embrio ayam umur 9 hari, 13 hari, 17 hari dan 21 hari tulang humerus, radius, ulna dan carpometacarpo telah mengalami osifikasi yang membedakan ialah pada tulang digitinya. Serta terjadi perkembangan tulang (osifikasi) disetiap pertambahan usia yang dilihat dari kecenderungan nilai data ukuran panjang dari tulang yang mengalami osifikasi. Pada kaki embrio ayam umur 9 hari, 13 hari, 17 hari dan 21 hari tulang femur, tibiotarsus dan tarsometatarsus telah mengalami osifikasi yang membedakan adalah tulang pada digitinya. Serta terjadi perkembangan tulang (osifikasi) disetiap pertambahan usia yang dilihat dari kecenderungan nilai data ukuran panjang dari tulang yang mengalami osifikasi.

\section{Ucapan Terima Kasih}

Peternak ayam Panca Murti Malang yang telah membantu dalam penyediaan bahan

\section{Daftar Pustaka}

[1] Wicaksono, D., Kurtini, T., Nova, K. 2013. Perbedaan Fertilitas Serta Susut, Daya dan Bobot Tetas Ayam buras pada Penetasan Kombinasi. Jurnal Ilmiah Peternakan Terpadu. Vol 1, No 2. URL: http//jurnal.fp.unila.ac.id/index/JIPT/article/view/159

[2] Nataamijaya, AG. 2010. Pengembangan potensi ayam lokal untuk menunjang peningkatan kesejahteraan petani. J.Litbang Pertanian. 29: 4.http//peternakan.litbang.pertanian.go.id

[3] Kusumawati , A., Rina, F., Shella, H., Mufti, SD., Ninik, I. 2016. Perkembangan Embrio dan Penentuan Jenis Kelamin DOC (Day-Old Chick) Ayam Jawa Super. Jurnal Sain Veteriner. 34(1): 29-41.http//jurnal.ugm.ac.id/artikel/view/22811.

[4] Wulandari R. 2014. Struktur dan Perkembangan Rangka Embrio Ayam (Gallus gallus domesticus Linneus, 1758) Hasil Persilangan Ayam Pelung dengan Ayam Broiler dan Ayam buras. Fakultas Biologi. Universitas Gajah Mada. Yogyakarta.

[5] Cook, C., and Philip, L. H. 2001. Management and organizational behavior (3 ed). Development and Activity in Chickens In Response To Reduced Weight. 
e-Jurnal Ilmiah BIOSAINTROPIS (BIOSCIENCE-TROPIC)

Volume 5/ No.: 2 / Halaman 30 - 37 / Januari Tahun 2020

ISSN : 2460-9455 (e) - 2338-2805(p)

[6] Nugroho, A.E. 2011. Evaluasi Pewarnaan Alcian blue Terhadap Sel Mast Jaringan Ikat Dari Preparat Beku Jaringan Kulit Kaki Tikus. Jurnal Pharmasi Indonesia. Vol 8, No 2 : 10-20. Diakses 28 November 2018 . URLhttp://jurnalnasional.ump.ac.id.

[7] Puspitasari, D., Djoko, J.B., Suparno, G. 2015. Kunyit (Curcuma Domestica Val.) Sebagai Pewarna Alternatif Pewarnaan Tulang Embrio Ayam (Gallus Gallus). BioEdu. Vol 4, No 1 : 827-831. . Diakses 5 Oktober 2018. URL: http://ejurnal.unesa.ac.id.

[8] Supriyadi., Fitriya, L., Agus, S., Aceng, R. 2013. Uji Teratogenisitas Ekstrak Kulit Batang Karas (Aquilaria malacensis) Pada Fetus Mencit (Mus musculus). Prosiding Semirata FMIPA Universitas Lampung, 2013. Vol 1, No 1:321-325.

[9] Soeminto. 2000. Embriologi Vertebrata. Fakultas Biologi UNSOED.Purwokerto

[10] Subowo. 1992. Histologi Umum. Penerbit Bunga Angkasa.Jakarta.

[11] Herren. 2000. The Science of Animal Agricultur, 2nd Edition. Delmar, New york. 